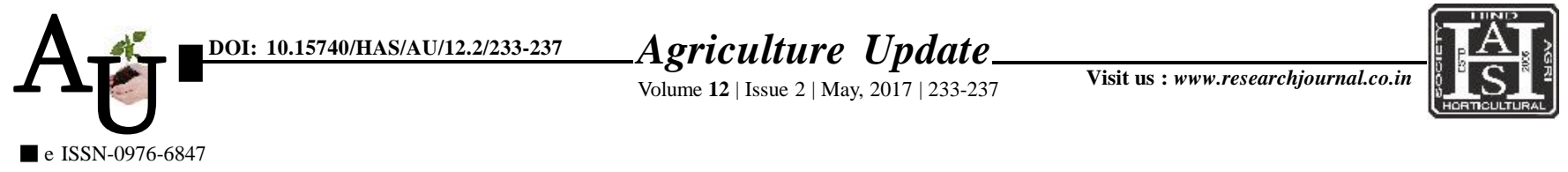

\title{
Research article: Association of cropping system over the period in Dharwad district of Karnataka
}

\author{
H.S. SOWMYA AND A.R.S. BHAT
}

Article Chronicle : Received :

23.02.2017;

Revised :

14.03.2017;

Accepted :

27.03.2017

\section{KeY Words :}

Global warming,

Cropping system, Co-

efficient of

concordance /

Kendall w-co-efficient

SUMMARY : Global warming is projected to have significant impacts on conditions affecting agriculture, including temperature, carbon dioxide, glacial run-off, precipitation and the interaction of these elements. Assessment of the effects of global climate changes on agriculture might help to properly anticipate and adapt suitable farming practices to maximize agricultural production. Hence, present study were conducted with the objective to know association of cropping system over the period in Dharwad district of Karnataka. Data used for the study were collected from Directorate of Economics and Statistics, Government of Karnataka, Bangalore for the crops like chilli, maize, groundnut, sorghum, cotton and soybean. Only two parameters considered namely area and price and the method used is co-efficient of concordance / Kendall w-co-efficient. Both area and price study revealed the association in cropping system over the years.

How to cite this article : Sowmya, H.S. and Bhat, A.R.S. (2017). Association of cropping system over the period in Dharwad district of Karnataka. Agric. Update, 12(2): 233-237; DOI : 10.15740/HAS/AU/12.2/233237.

\section{Author for correspondence :}

\section{H.S. SOWMYA}

Department of

Agricultural Statistics,

University of

Agricultural Sciences,

DHARWAD (KARNATAKA)

INDIA

Email:hssom737@gmail.

com

See end of the article for

authors' affiliations 